\title{
Squalene Extraction by Supercritical Fluids from Traditionally Puffed Amaranthus hypochondriacus Seeds
}

\author{
Teresa Rosales-García, ${ }^{1,2}$ Cristian Jiménez-Martínez, \\ Anaberta Cardador-Martínez, ${ }^{3}$ Sandra Teresita Martín-del Campo, ${ }^{3}$ Luis A. Galicia-Luna, ${ }^{2}$ \\ Dario Iker Téllez-Medina, ${ }^{1}$ and Gloria Dávila-Ortiz ${ }^{1}$
}

\author{
${ }^{1}$ Departamento de Ingeniería Bioquímica, Escuela Nacional de Ciencias Biologicas, Instituto Politécnico Nacional, \\ UPALM, Zacatenco, Av. Wilfrido Massieu, Esq. Cda. Manuel Stampa S/N, CP 07738, Delegación Gustavo A. Madero, \\ Ciudad de México, Mexico \\ ${ }^{2}$ Laboratorio de Termodinámica, SEPI-ESIQIE, Instituto Politécnico Nacional, UPALM, Edif. Z, Secc. 6, \\ 1ER Piso Lindavista, CP 07738, Ciudad de México, Mexico \\ ${ }^{3}$ Escuela de Ingeniería y Ciencias, Tecnológico de Monterrey, Querétaro, QRO, Mexico
}

Correspondence should be addressed to Gloria Dávila-Ortiz; gdavilao@yahoo.com

Received 2 August 2017; Revised 11 October 2017; Accepted 9 November 2017; Published 4 December 2017

Academic Editor: Domenico Montesano

Copyright (C) 2017 Teresa Rosales-García et al. This is an open access article distributed under the Creative Commons Attribution License, which permits unrestricted use, distribution, and reproduction in any medium, provided the original work is properly cited.

\begin{abstract}
Extraction of squalene, a potent natural antioxidant, from puffed A. hypochondriacus seeds was performed by supercritical fluid extraction (SCFE); besides, to have a blank for comparison, extraction was performed also by Soxhlet method using organic solvents (hexane). Chemical proximal composition and seed morphology were determined in raw, puffed, and SCFE-extracted seeds. Extracts were obtained with a $500 \mathrm{~mL}$ capacity commercial supercritical extractor and performed between 10 and $30 \mathrm{MPa}$ at 313,323 , and $333 \mathrm{~K}$ under constant $\mathrm{CO}_{2}$ flow of $0.18 \mathrm{~kg} \mathrm{CO}_{2} / \mathrm{h}$ during $8 \mathrm{~h}$. The squalene content was determined and the fatty acids present in the extracts were identified by GC-MS. The extract obtained by SCFE from puffed amaranth seeds reached $460 \pm$ $28.1 \mathrm{~g} / \mathrm{kg}$ squalene in oily extract at $313 \mathrm{~K} / 20 \mathrm{MPa}$.
\end{abstract}

\section{Introduction}

Amaranth is an ancient crop widely harvested in the Americas, which is appreciated by its nutritional benefits and its religious ancient significance [1]. Amaranthus hypochondriacus is one of most important amaranth species and it is harvested in Mexico since pre-Columbian times to current days [2]. One common way to commercialize amaranth seeds is through swelling them by a puffing process [3]. Puffed amaranth seeds are obtained by heat that produces water vaporization and steam accumulation, which increases pressure until the coat breaks and separates from the rest of the seed [4]; thus, starch granules are forced to expand and to convert into a foam matrix [5].

Consumption of amaranth seeds has increased the interest of many researchers in this crop [6]. Amaranth oily extract is constituted mainly by fatty acids and, in minor concentrations, unsaponifiable matter such as squalene [1].

Squalene is a triterpene $\left(\mathrm{C}_{30} \mathrm{H}_{50}\right)$ commonly found in plants and animal tissues also, with a role as intermediate in phytosterols and cholesterol biochemical pathways [7]. Several research works have reported its biochemical importance as antioxidant [8-10] and chemopreventive agent [11]. During the last century, shark liver oil was the largest source of squalene extraction [12]; however, nowadays vegetable sources are mostly exploited such as olive oil $[13,14]$ and oily seeds $[12,15]$. Selective extraction from plants to obtain bioactive substances is achieved with appropriate solvents and methods [16]. Squalene is of high commercial importance; for example, 2500 tons with a commercial value of 93 million dollars were produced in 2013 [17] and highly demanded by the cosmetics, food, and pharmaceutical industries [7, 17]. 
Different techniques are used to obtain the oily fraction from amaranth seeds. The literature has compared three techniques, expeller pressing, organic solvent extraction, and supercritical fluid extraction (SCFE) showing that the best yield is achieved $69.5 \mathrm{~g} / \mathrm{kg}$ by SCFE [18]. Other methods had been proved by Krulj et al. [19] who extracted amaranth oil from raw seeds using accelerated solvent extraction and achieved higher yield than supercritical fluid extraction 78.1 and $61.1 \mathrm{~g} / \mathrm{kg}$, respectively. Relatively low temperature extraction results in almost no-thermal degradation of labile compounds. One advantage about SCFE is that the extracts and matrices are solvent-free; vegetables matrices after extraction can be exploited for foodstuff purposes [20]. Among substances used as solvents in SCFE, carbon dioxide $\left(\mathrm{CO}_{2}\right)$ is commonly used by its known characteristics as an ecofriendly, inert, economic, selective, and nontoxic compound $[21,22]$. SCFE as free solvent process allows the absence of squalene oxidation products and the presence of phenolic compounds in extract [23]. Usually, SCFE is proved under several pressure, temperature, flow, and time conditions; Yin et al. [24] used not only experimental conditions, but also mathematical simulation to predict the best extraction conditions.

Previous works have already performed SCFE from amaranth seeds previously ground to obtain amaranth oily fractions $[22,25,26]$. As mentioned above, the most common presentation to commercialize amaranth is a puffed seeds; milling seeds would limit its commercialization, increasing steps in extraction process and rising production cost; however, it is possible to obtain oily extracts from nonmilled raw seeds, although with relatively low yields $[19,22]$.

The aim of this work was to obtain squalene by SCFE from whole puffed amaranth seeds and to compare the squalene content obtained by Soxhlet extraction, as well as determining the possible morphological and chemical modifications in the seeds.

\section{Methodology}

2.1. Materials and Supplier Information. Carbon dioxide (CAS number 124-38-9) 99.995\% pure was provided by Infra (Mexico). Squalene (CAS number 111-02-4) 99.0\% pure was provided by SIGMA. Amaranth (Amaranthus hypochondriacus) raw and puffed seeds from the same batch were kindly donated by a manufacturer from Puebla, Mexico, harvested in November 2013. Puffing conditions were not provided by the supplier.

2.2. Chemical Proximal Characterization. Main components (water, proteins, lipids, and ashes) of puffed seeds were determined by standard methods; water content m.b. (g/100 g) by method 925.09; proteins by the Kjeldahl method 920.87; lipid content (g/100 g) with Soxhlet 920.39; ashes by 942.05 [27]. Finally, nonnitrogenous matter was calculated by difference; the obtained results were reported as the average of three repetitions \pm standard deviation.

2.3. Seed Morphology. Amaranth, nonpuffed, and puffed seeds as well as seeds after extraction were observed under an optical microscope (Nikon Eclipse Ci) at 60x. Images for no less than 100 seeds were captured by a camera attached to the microscope tube with $1600 \times 1200$ pixels resolution and JPEG format. Images were processed using the ImageJ $1.50 \mathrm{c}$ software (Wayne Rasband, National Institutes of Health, USA) with automatic threshold and analyzed in binary format to determine size and shape parameters as follows: area: the total pixels of the projected area of each analyzed seed; perimeter: number of pixels constituting the contour of the projected area of the seed; circularity: defined as $4 \pi$ multiplied by area and divided by perimeter squared; a perfect circle has circularity equal to 1; Feret's diameter: widest distance of two pixels at different object orientations; and aspect ratio: relation between maximum and minimum axes. The scale used was 0.5253 pixels $/ \mu \mathrm{m}$.

2.4. Expansion Ratio. Expansion ratio is the quotient from dividing the apparent bulk volume of nonpuffed and puffed seeds. Bulk volume was measured with a graduated cylinder using the same mass of seeds ( $60 \mathrm{~g}$ ) according to Murakami et al. [28]. Results were reported as averages of three repetitions and their respective standard deviation.

\subsection{Amaranth Oily Extraction}

2.5.1. SCFE. SCFE was carried out through dynamic method using the Thar Technologies (SFE-500 model) extraction plant (see Figure 1) located at ESIQIE-IPN in Mexico City, Mexico. This extraction plant is composed of a high pressurepump (BS) which supplies liquid $\mathrm{CO}_{2}$, two heat exchangers, a cooler (ICE) located behind the high pressure-pump, and a heater (ICC) located at the mixer's (MX) exit. The MX function is to introduce a cosolvent (SC) and mix it with $\mathrm{CO}_{2}$ if necessary. Two valves (RAPI and RMPI) avoid pressure backward in tubes. Temperature and pressure conditions influence the amount of extracted oily matter; hence, studied conditions ranged by $313-333 \mathrm{~K}$ and $10-30 \mathrm{MPa}$, respectively. Carbon dioxide was used as solvent at constant flow $(0.18 \mathrm{Kg}$ $\mathrm{CO}_{2} / \mathrm{h}$ ) for $8 \mathrm{~h}$, and $\mathrm{SC}-\mathrm{CO}_{2}$ passed through the puffed seeds $(60 \mathrm{~g})$ in the extractor (E) vessel and separator vessel (S) at lower pressure, both with $500 \mathrm{~mL}$ capacity. Amaranth extracts were collected from the separator vessel, weighed, and analyzed.

2.5.2. Soxhlet Method. Organic solvent extraction using a Soxhlet apparatus was performed with $60 \mathrm{~g}$ of puffed amaranth seeds and an excess of hexane that condensed and recirculated throughout the Soxhlet distillation path for $8 \mathrm{~h}$ at $68^{\circ} \mathrm{C}$ and atmospheric pressure. To compare the amount obtained by both extraction methods, all the extracts were stored at $277 \mathrm{~K}$ under a nitrogen atmosphere to minimize thermal and oxidative degradation. Effectiveness contact area was maximized by using milled seeds as described by Wejnerowska et al. [22]. Hexane is typically the solvent used for large scale extractions due to its relatively low cost and high extraction efficiency [29].

2.6. Squalene Identification and Quantification. Squalene content in SCFE extracts was preliminary determined as 


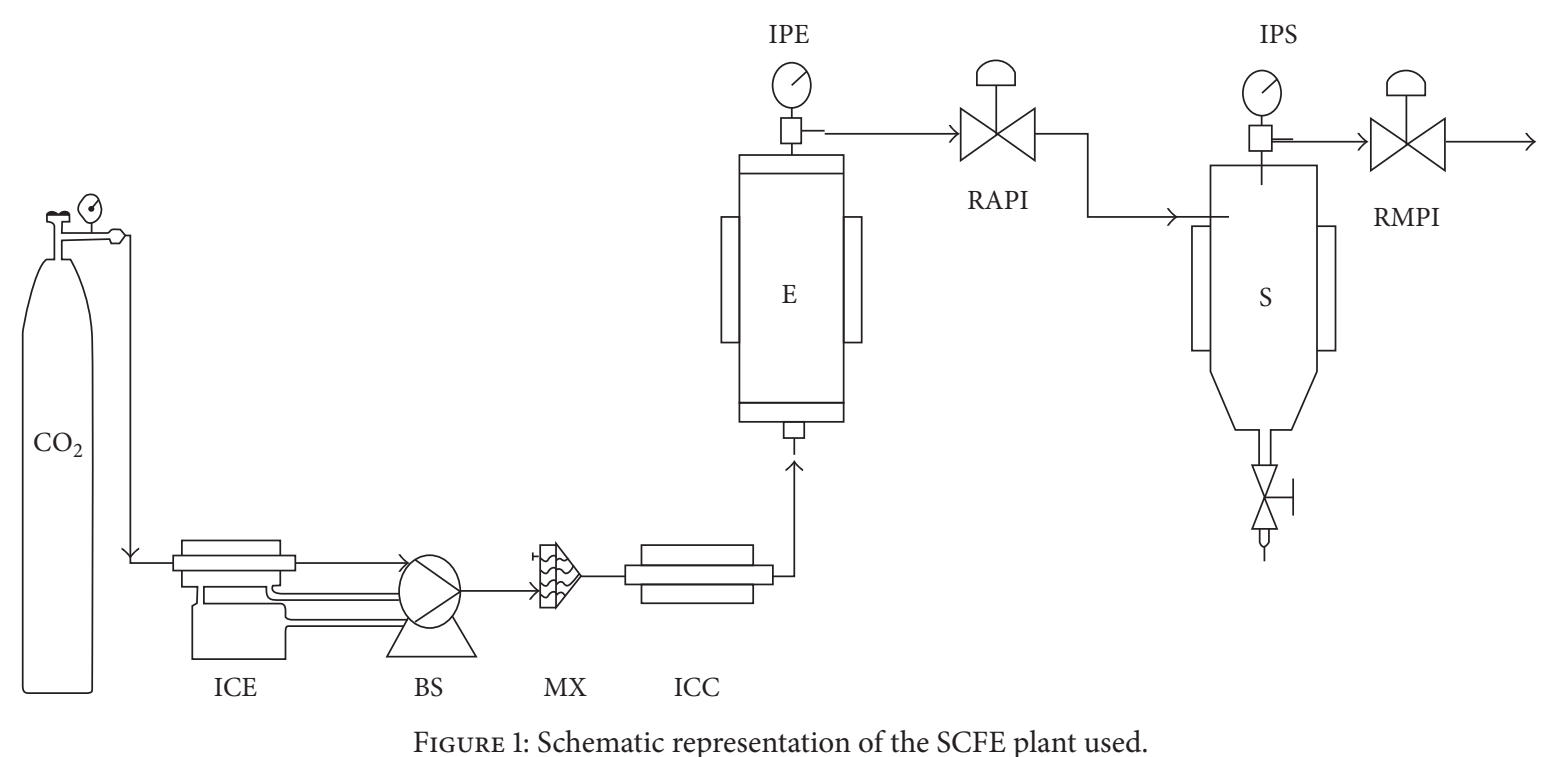

described by Schneider [30], by means of high performance liquid chromatography (HPLC) at $208 \mathrm{~nm}$, mobile phase composed of acetonitrile and acetone (60:40\% volume). The HPLC apparatus has been described previously by RojasÁvila et al. [31]. Soxhlet and SCFE extracts were analyzed quantitatively by gas chromatography coupled to mass spectrometry (GC-MS); GS-MS conditions are outlined below. Squalene was quantified with a corresponding eight-point standard curve, coefficient of determination $\left(r^{2}\right)$ of 0.98 .

2.7. Fatty Acids Identification and Quantification. The obtained extracts were analyzed according to Aquino-Bolaños et al. [32] in a gas chromatograph (GC) Agilent 7890A (Agilent Technologies, Palo Alto, CA, USA) coupled to mass spectrometry (MS) system Agilent 5975C, split ratio 2:1. Sample separation was achieved using a column HP-88 ((88\% cyanopropyl) aryl-polysiloxane, $100 \mathrm{~m} \times 0.25 \mathrm{~mm}$ ID $0.20 \mu \mathrm{m}$, Agilent Technologies). Carrier gas used was helium at $6.6 \mathrm{~mL} / \mathrm{min}$ flow. The temperature set in injector and transfer line was $250^{\circ} \mathrm{C}$. Oven was heated through the following temperature rate: initial temperature was $50^{\circ} \mathrm{C}$, increased by $2.5^{\circ} \mathrm{C} / \mathrm{min}$ up to $85^{\circ} \mathrm{C}$ and then $10^{\circ} \mathrm{C} / \mathrm{min}$ up to $170^{\circ} \mathrm{C}$, hold for $20 \mathrm{~min}$, and then increased by $10^{\circ} \mathrm{C} / \mathrm{min}$ up to $250^{\circ} \mathrm{C}$ to allow fatty acid methyl esters separation (FAMEs) in a total run time of $87.5 \mathrm{~min}$. Identification was conducted using the NIST 05 library. Fatty acids were quantified as relative area percent using squalene as internal standard.

\section{Results and Discussion}

3.1. Chemical Proximal Characterization. In the present work, the main components of $A$. hypochondriacus seeds (raw, puffed, and puffed-SCFE) were determined. Soxhletextracted seeds were not considered for further determination due to the elevated content of hexane after extraction and its potential toxicity in foodstuff formulations. Table 1 shows moisture, ashes, protein, lipid, and nonnitrogenous matter content in seeds. Minimum changes in composition due to the SCFE process may indicate the possibility of exploiting amaranth puffed seeds in food products after this type of extraction. Seed moisture content decreased due to the puffing process (heat treatment), which produced water evaporation [33]. SCFE diminished humidity even more, probably because seeds were kept during $8 \mathrm{~h}$ under constant temperature and $\mathrm{CO}_{2}$ flow. Lipid content in puffed seeds may decrease because of partial loss of the peripheral embryo where most of lipids are contained; the same effect has been observed in A. cruentus and A. caudatus [34]. In addition, ash content is mainly constrained to the seed coat [35], and the coat may be lost during puffing, decreasing mineral content. It is important to point out that no protein and carbohydrates loss occurred due to SCFE. Under these conditions, seeds might be used for different foodstuff purposes after SCFE.

3.2. Morphology Changes. Morphology characteristics of raw, puffed, and SCFE after puffing seeds are shown in Table 2. Among the parameters evaluated, area of raw and puffed seeds presented an increment from $1.98 \pm 0.7$ to $5.92 \pm$ $0.93 \mathrm{~mm}^{2}$ due to structural changes which occurred in carbohydrates by puffing processes. Amaranthus cruentus raw seeds reported area of 3.26 to $3.60 \mathrm{~mm}^{2}$ at $9.5 \%$ moisture content [36]. Perimeter seed also increased from $2.90 \pm 0.07$ to $4.72 \pm 0.07$ as a result of heat treatment. Feret's diameter increased from $0.99 \pm 7.3 \times 10^{-3}$ to $1.67 \pm 0.02^{\mathrm{b}} \mathrm{mm}$; $1.35 \mathrm{~mm}$ and 0.80 to $1.00 \mathrm{~mm}$ diameter corresponds to raw Amaranthus cruentus and Amaranthus sp. seeds, respectively $[36,37]$. In raw amaranth, seed dimensions are influenced by water content according to Abalone et al. [38]. Morphology differences are also due to amaranth species as described by others [1]. SCFE does not seem to affect morphology parameters (area, perimeter, and Feret's diameter) and shape descriptors (circularity and aspect ratio) due to supercritical carbon dioxide $\mathrm{SC}-\mathrm{CO}_{2}$ noninvasive and easily removing properties [37]; thus, SCFE-puffed seeds could be used in 
TABLE 1: Chemical proximal characterization of raw, puffed, and SCFE-extracted A. hypochondriacus seeds.

\begin{tabular}{lccc}
\hline Parameter $(\mathrm{g} / 100 \mathrm{~g})$ & Raw seeds & Puffed seeds & SCFE extracted seeds \\
\hline Moisture & $10.50 \pm 0.15^{\mathrm{a}}$ & $8.67 \pm 0.04^{\mathrm{b}}$ & $7.11 \pm 0.08^{\mathrm{c}}$ \\
Ash $^{*}$ & $3.55 \pm 0.03^{\mathrm{a}}$ & $3.21 \pm 0.05^{\mathrm{b}}$ & $3.19 \pm 0.07^{\mathrm{b}}$ \\
Protein $^{*}$ & $13.68 \pm 0.41^{\mathrm{a}}$ & $13.37 \pm 0.16^{\mathrm{a}}$ & $13.43 \pm 0.09^{\mathrm{a}}$ \\
Lipid content $^{*}$ & $10.32 \pm 0.14^{\mathrm{a}}$ & $9.19 \pm 0.31^{\mathrm{b}}$ & $8.57 \pm 0.12^{\mathrm{c}}$ \\
Nonnitrogenous matter $^{* *}$ & $72.45 \pm 0.21^{\mathrm{a}}$ & $74.23 \pm 0.19^{\mathrm{b}}$ & $74.81 \pm 0.14^{\mathrm{c}}$ \\
\hline
\end{tabular}

${ }^{*}$ Dry basis. ${ }^{* *}$ Obtained by difference. Different letters mean statistically significant difference at $2 \alpha=0.05$ level, evaluated by Tukey test.

TABLE 2: Morphology of raw, puffed, and SCFE-extracted A. hypochondriacus seeds.

\begin{tabular}{lccc}
\hline Parameter & Raw seeds & Puffed seeds & SCFE-extracted seeds \\
\hline Area $\left(\mathrm{mm}^{2}\right)$ & $1.98 \pm 0.7^{\mathrm{a}}$ & $5.92 \pm 0.93^{\mathrm{b}}$ & $5.26 \pm 0.7^{\mathrm{b}}$ \\
Perimeter (mm) & $2.90 \pm 0.07^{\mathrm{a}}$ & $4.72 \pm 0.07^{\mathrm{b}}$ & $4.46 \pm 0.05^{\mathrm{b}}$ \\
Circularity (dimensionless) & $0.97 \pm 0.08^{\mathrm{a}}$ & $1.00 \pm 0.03^{\mathrm{a}}$ & $1.00 \pm 0.03^{\mathrm{a}}$ \\
Feret's diameter (mm) & $0.99 \pm 7.3 \times 10^{-3 \mathrm{a}}$ & $1.67 \pm 0.02^{\mathrm{b}}$ & $1.57 \pm 0.01^{\mathrm{b}}$ \\
Aspect ratio (dimensionless) & $1.06 \pm 0.03^{\mathrm{a}}$ & $1.15 \pm 0.15^{\mathrm{a}}$ & $1.14 \pm 0.09^{\mathrm{a}}$ \\
\hline
\end{tabular}

Different letters mean statistically significant difference at $2 \alpha=0.05$ level, evaluated by Tukey test.

food processing in the same way as nonextracted puffed seeds are used.

The expansion ratio is related to seed size change and puffing efficiency; this parameter was $6.09 \pm 0.27$, which refers to an increase in volume seed due to puffing. At similar water content and $225^{\circ} \mathrm{C}$, expansion ratio was about 9.6 when a fluidized bed system was used for puffing. Traditional puffing process usually reports low efficiency and inhomogeneity [39]. The increase in contact surface influences extraction, as previously reported [40-42].

3.3. Amaranth Oily Extract. A. hypochondriacus oily extracts were obtained by SCFE and Soxhlet methods from puffed seeds. Soxhlet yield of total oily matter was $10.32 \%$ and 9.19\% for raw and puffed seeds, respectively; the highest content of oily matter from amaranth by SCFE was attained at $333 \mathrm{~K} / 30 \mathrm{MPa}(1.79 \%)$ as shown in Figure 2. Higher content of oily matter has been obtained under higher pressure and temperature conditions; this behavior is commonly reported as a result of temperature increase and competition factors related to solvent density and solute-vapor pressure $[26,43]$. Although the oily mass extracted was determined, squalene content in extracts defined the best extraction conditions. Lower operation conditions (temperature and pressure) would be unstable to supercritical fluids and difficult to maintain by SCFE plant, whereas higher temperature conditions could compromise squalene stability as described by Psomiadou and Tsimidou [44]; finally, higher pressure will not be achieved due to pressure-pump capabilities at the established flow.

3.4. Squalene Identification and Quantification. The content of squalene in extracts obtained by SCFE was determined by HPLC; the results are shown in Figure 3. It can be observed that at $313 \mathrm{~K} / 20 \mathrm{MPa}$ and $333 \mathrm{~K} / 15 \mathrm{MPa}$ there was no

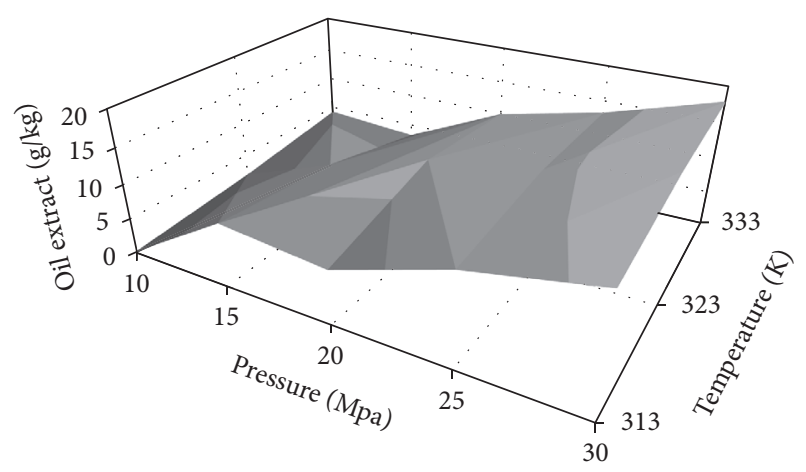

FIGURE 2: Effect of temperature and pressure on total oily amaranth extract $[\mathrm{g} / \mathrm{kg}]$ obtained by SCFE from amaranth puffed seeds.

difference in squalene content in extracts obtained, although yield was higher at $313 \mathrm{~K} / 20 \mathrm{MPa}$. Soxhlet extraction was applied to raw and puffed seeds and squalene content of extracts was determined by GC-MS, as shown in Figure 4. Squalene content in Soxhlet oily extracts was $44.2 \pm 2.27$ and $31.3 \pm 1.0$ squalene $\mathrm{g} / \mathrm{kg}$ of oily extract from whole raw and puffed seeds respectively, whereas SCFE extraction from whole puffed seeds yielded $460 \pm 28.1 \mathrm{~g} / \mathrm{kg}$ squalene in the oily extract. Krulj et al. [19] obtained an average oily extract yield of $58.4 \mathrm{~g} / \mathrm{kg}$ and $3.5 \mathrm{~g} / \mathrm{kg}$ of squalene by applying SCFE in milled raw seeds. Our results indicate that SCFE extracts had a higher squalene content than Soxhlet-extracts when puffed seeds are used, suggesting that puffing not only gives better physical, functional, and mechanical properties [36] but also makes more available oil and particularly squalene for extraction.

Other authors have obtained the amaranth oily extract from seeds using A. cruentus [25] and obtained $148.8 \mathrm{~g} / \mathrm{kg}$ of squalene in the oily extract at $313 \mathrm{~K} / 15 \mathrm{MPa} / 180 \mathrm{~min}$. 


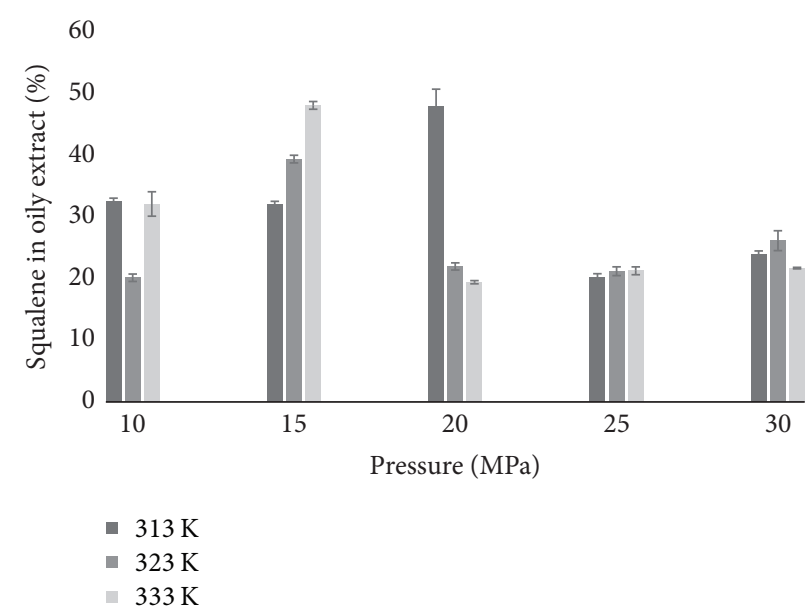

FIGURE 3: Squalene content in amaranth oily extracts (\%) obtained at different operating conditions by SCFE from puffed seeds.

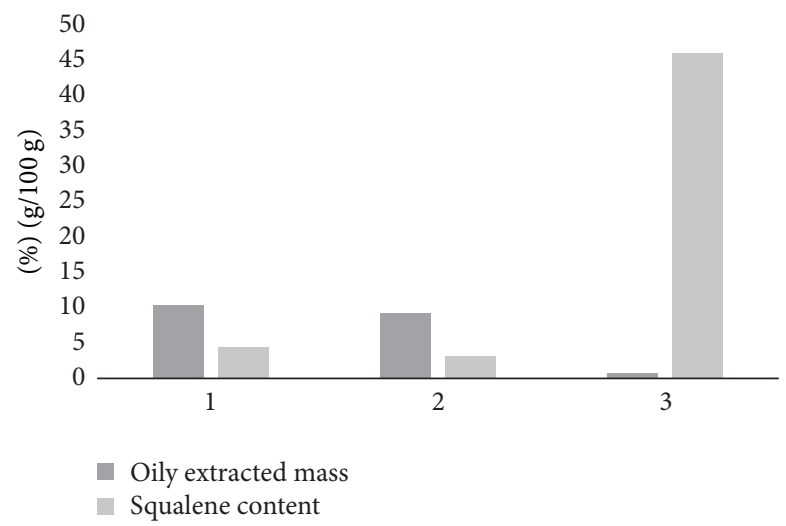

FIGURE 4: Oily extracted mass in seeds and squalene content in oily extracts (g/100 g). (1) Raw seeds hexane extract; (2) puffed seeds hexane extract; (3) puffed seeds SCFE extract.

Czaplicki et al. [18] attained $69.5 \mathrm{~g} / \mathrm{kg}$ of squalene at $323 \mathrm{~K} / 31 \mathrm{MPa} / 16 \mathrm{~h}$. Wejnerowska et al. [22] obtained up to $600 \mathrm{~g} / \mathrm{kg}$ of squalene at $403 \mathrm{~K} / 20 \mathrm{MPa} / 30 \mathrm{~min}$. Increasing temperature favored squalene purity and reduced yield simultaneously. He et al. [33] reached $153 \mathrm{~g} / \mathrm{kg}$ of squalene at $323 \mathrm{~K} / 20 \mathrm{MPa} / 2 \mathrm{~h}$. Finally, Westerman et al. [26] using ground Amaranthus spp. seeds at $323 \mathrm{~K} / 30 \mathrm{MPa} / 21 \mathrm{~h}$ extracted up to $65.7 \mathrm{~g} / \mathrm{kg}$ squalene. The squalene content in the extract obtained in this work was $460 \pm 28.1 \mathrm{~g} / \mathrm{kg}$ as described above, at lower pressure and temperature compared to reference works using whole puffed seeds; this might represent an important advantage at industrial scale, avoiding the solvent removal stage and reducing costs since the whole seeds can be reused for further food purposes. Differences in squalene content in SCFE may be related to amaranth species used; longer extraction time could increase squalene extraction [22].

3.5. Fatty Acids Identification and Quantification. Amaranth seeds fatty acids composition was determined through GCMS. The obtained results are shown in Table 3. Some of the identified unsaturated fatty acids were oleic, linoleic, linolenic, and arachidonic, whereas saturated acids were myristic, palmitic, margaric, and stearic. Oleic (C18:1), linoleic (C18:2), and linolenic (C18:3) acids are commonly present in some vegetal oils [45] and are known for their health benefits [46]; they are also used as raw material for bioproducts elaboration [47]. Arachidonic acid (C20:4) functions as signaling molecule regulating inflammation and acting on homeostasis [48, 49]. Myristic (C14:0), palmitic (C16:0), margaric (17:0), and stearic (C18:0) acids are generally found in unprocessed fats [50], easily to crystallize at room temperature [51], and demanded by oleochemical industry [52] such as palm oil, due to their composition; therefore, an oily extract with similar composition may be demanded as well [53].

Fatty acids content in crude extract obtained from raw ground Amaranthus caudatus seeds by SCFE ( $313 \mathrm{~K} / 20 \mathrm{MPa}$ ) contained palmitic acid $19.89 \%$, stearic acid $2.55 \%$, oleic acid $25.47 \%$, and linoleic acid $25.47 \%$ [54]. The SCFE extract in the present work contains more palmitic $(28.71 \pm 0.35 \%)$, stearic $(6.05 \pm 0.07 \%)$, and oleic acids $(28.68 \pm 0.35 \%)$ and less linoleic acid $(18.95 \pm 0.23 \%)$; this could be obtained by differences in flow rate $\left(0.12 \mathrm{Kg} \mathrm{CO}_{2} / \mathrm{h}\right)$ and extraction time $(14 \mathrm{~min})$ and Amaranth species used.

SCFE-amaranth extract contained more unsaturated than saturated fatty acids and lower concentrations of oleic and palmitic acids than olive and palm oils $[55,56]$; it also had higher content of linoleic, linolenic, and arachidonic acids than olive and palm oils $[55,56]$. SCFE extract compared to palm oil had similar palmitic/oleic ratio; however, its content of unsaturated fatty acids may be advantageous and healthier. Distribution of saturated and unsaturated fatty acids (palmitic and oleic acid, $28.71 \%$ and $28.78 \%$, resp.) agrees with the experimental localization of squalene in cell membrane as reported by Hauß et al. [57] who showed that squalene is immersed in the lipid bilayer, where a balance between saturated and unsaturated fatty acids exists.

Squalene content in olive oil was reported in the range of 110 to $839 \mathrm{mg} / 100 \mathrm{~g}$ [14] and $2-4 \mathrm{~g} / 100 \mathrm{~g}$ (wt\%) in palm fatty acid distillate $[53,58,59]$. Amaranth extract obtained in this work reached, then, an acceptable purity as described above. 
TABLE 3: Fatty acids content (mg/ml) from A. hypochondriacus extracts determined by GC-MS.

\begin{tabular}{lccc}
\hline Fatty acid & Raw seeds Soxhlet extract & Puffed seeds Soxhlet extract & Puffed seeds SCFE extract \\
\hline Myristic acid & $0.09 \pm 1.4 e^{-3 \mathrm{a}}$ & $0.08 \pm 5 e^{-3 \mathrm{~b}}$ & $0.11 \pm 4.4 e^{-3 \mathrm{c}}$ \\
Palmitic acid & $9.56 \pm 0.12^{\mathrm{a}}$ & $9.27 \pm 8.3 e^{-3 \mathrm{~b}}$ & $10.71 \pm 0.35^{\mathrm{c}}$ \\
Margaric acid & $\mathrm{NI}$ & $\mathrm{NI}$ & $0.54 \pm 0.02$ \\
Stearic acid & $0.56 \pm 9 e^{-3 \mathrm{a}}$ & $2.39 \pm 2 e^{-3 \mathrm{~b}}$ & $2.25 \pm 0.07^{\mathrm{c}}$ \\
Oleic acid & $10.84 \pm 0.14^{\mathrm{a}}$ & $9.34 \pm 4 e^{-3 \mathrm{~b}}$ & $10.67 \pm 0.35^{\mathrm{c}}$ \\
Linoleic acid & $11.00 \pm 0.14$ & $7.03 \pm 5.2 e^{-3}$ & $7.05 \pm 0.23$ \\
Linolenic acid & $0.47 \pm 3.9 e^{-3 \mathrm{a}}$ & $0.10 \pm 2.5 e^{-3 \mathrm{~b}}$ & $0.41 \pm 0.01^{\mathrm{c}}$ \\
Arachidonic acid & $0.16 \pm 2.3 e^{-3 \mathrm{a}}$ & $0.65 \pm 3.6 e^{-3 \mathrm{~b}}$ & $0.58 \pm 0.01^{\mathrm{c}}$ \\
\hline
\end{tabular}

$\mathrm{NI}=$ not identified. Different letters mean statistically significant difference at $2 \alpha=0.05$ level, evaluated by Tukey test.

This work showed that SCFE extract from puffed amaranth seeds contains squalene accompanied by some unsaturated fatty acids. A. hypochondriacus puffed seeds after SCFE mostly preserved their nutritional components, such as proteins and carbohydrates, and presented a remnant lipid content, including some fatty acids important for human diet. Flour from defatted amaranth has been already used to supplement bread flour without modifications in bread quality by increasing protein and especially lysine content [60]. Further investigation should explore SCFE with mixtures with different cosolvents in order to increase yield, producing squalene extracts even more enriched from puffed amaranth seeds. Due to minimal changes in chemical composition and morphometric characteristics, it is reasonable to consider the further use of SCFE-extracted puffed amaranth seeds in food industry. Growing cosmetic and food industries surely will cause the squalene market to rise in the future which increases the marine life concerns, claiming new research on squalene extraction from vegetable sources [17].

\section{Conclusion}

SCFE was satisfactorily applied to obtain a greater amount of oily extract rich in squalene from whole puffed amaranth seeds $(460 \pm 28.1 \mathrm{~g} / \mathrm{kg})$ than what is obtained through hexane extraction; furthermore, seeds main composition remains after SCFE. High squalene extract was achieved through SCFE with $\mathrm{CO}_{2}$ at $313 \mathrm{~K} / 20 \mathrm{MPa}$. The Soxhlet method might be inconvenient due to solvent removal final stage; in SCFE, such stage may be avoided. Puffing of amaranth seeds affects their nutritional content; however, the effect of SCFE on nutrient content and morphology of puffed seeds is negligible, so that SCFE-extracted puffed seeds can be reused as regular puffed seeds in food processing. SCFE oily extract contains fatty acids such as palmitic, oleic, and linoleic acids in convenient quantity for human consumption.

\section{Conflicts of Interest}

The authors declare that they have no conflicts of interest regarding the publication of this paper.

\section{Acknowledgments}

The authors would like to acknowledge Instituto Politécnico Nacional and CONACyT for the financial support of this research and Doctoral Scholarship (300757) to Teresa Rosales Garcia.

\section{References}

[1] K. Arendt-Elke and E. Zannini, "Amaranth, Cereal Grains for the Food and Beverage Industries. A volume," in Technology and Nutrition, vol. 248, pp. 439-473, in Woodhead Publishing Series in Food Science, 2013.

[2] J. Milán-Carrillo, A. Montoya-Rodríguez, R. Gutiérrez-Dorado, X. Perales-Sánchez, and C. Reyes-Moreno, "Optimization of Extrusion Process for Producing High Antioxidant Instant Amaranth (Amaranthus hypochondriacus L.) Flour Using Response Surface Methodology," Applied Mathematics, vol. 03, no. 10, pp. 1516-1525, 2012.

[3] A. V. Ayala-Garay, E. Espitia-Rangel, P. Rivas-Valencia, G. Martínez-Trejo, and G. Almaguer-Vargas, "Análisis de la cadena del valor de amaranto en México.", Agricultura Sociedad y Desarrollo, vol. 13, no. 1, p. 87, 2016.

[4] M. Castro-Giráldez, P. J. Fito, J. M. Prieto, A. Andrés, and P. Fito, "Study of the puffing process of amaranth seeds by dielectric spectroscopy," Journal of Food Engineering, vol. 110, no. 2, pp. 298-304, 2012.

[5] H. G. Schwartzberg, J. P. C. Wu, A. Nussinovitch, and J. Mugerwa, "Modelling deformation and flow during vapor-induced puffing," Journal of Food Engineering, vol. 25, no. 3, pp. 329-372, 1995.

[6] P. R. Venskutonis and P. Kraujalis, "Nutritional Components of Amaranth Seeds and Vegetables: A Review on Composition, Properties, and Uses," Comprehensive Reviews in Food Science and Food Safety, vol. 12, no. 4, pp. 381-412, 2013.

[7] Z.-R. Huang, Y.-K. Lin, and J.-Y. Fang, "Biological and pharmacological activities of squalene and related compounds: Potential uses in cosmetic dermatology," Molecules, vol. 14, no. 1, pp. 540-554, 2009.

[8] Y. Aguilera, M. E. Dorado, F. A. Prada, J. J. Martínez, A. Quesada, and V. Ruiz-Gutiérrez, "The protective role of squalene in alcohol damage in the chick embryo retina," Experimental Eye Research, vol. 80, no. 4, pp. 535-543, 2005.

[9] Y. Kohno, Y. Egawa, S. Itoh, S.-I. Nagaoka, M. Takahashi, and K. Mukai, "Kinetic study of quenching reaction of singlet oxygen and scavenging reaction of free radical by squalene in $\mathrm{n}$ butanol," Biochimica et Biophysica Acta (BBA) - Lipids and Lipid Metabolism, vol. 1256, no. 1, pp. 52-56, 1995.

[10] F. Warleta, M. Campos, Y. Allouche et al., "Squalene protects against oxidative DNA damage in MCF10A human mammary 
epithelial cells but not in MCF7 and MDA-MB-231 human breast cancer cells," Food and Chemical Toxicology, vol. 48, no. 4, pp. 1092-1100, 2010.

[11] C. V. Rao, H. L. Newmark, and B. S. Reddy, "Chemopreventive effect of squalene on colon cancer," Carcinogenesis, vol. 19, no. 2, pp. 287-290, 1998.

[12] S. Czaplicki, D. Ogrodowska, D. Derewiaka, M. Tańska, and R. Zadernowski, "Bioactive compounds in unsaponifiable fraction of oils from unconventional sources," European Journal of Lipid Science and Technology, vol. 113, no. 12, pp. 1456-1464, 2011.

[13] D. Boskou, "Olive Oil," in Vegetable Oils in Food Technology: Composition, Properties and Uses, F. Gunstone, Ed., pp. 243-271, John Wiley Sons, Oxford, UK, 2011.

[14] G. Beltrán, M. E. Bucheli, M. P. Aguilera, A. Belaj, and A. Jimenez, "Squalene in virgin olive oil: Screening of variability in olive cultivars," European Journal of Lipid Science and Technology, vol. 118, no. 8, pp. 1250-1253, 2016.

[15] T. H. J. Beveridge, T. S. C. Li, and J. C. G. Drover, "Phytosterol content in American ginseng seed oil," Journal of Agricultural and Food Chemistry, vol. 50, no. 4, pp. 744-750, 2002.

[16] E. García-Márquez, A. Roman-Guerrero, C. Perez-Alonso, F. Cruz-Sosa, R. Jimenez-Alvarado, and E. J. Vernon-Carter, "Effect of solvent-temperature extraction conditions on the initial antioxidant activity and total phenolic content of muitle extracts and their decay upon storage at different $\mathrm{pH}$," Revista Mexicana de Ingeniería Química, p. 10, 2012.

[17] Global Market Insight, Squalene Market Size, Share, PriceIndustry Report, 2016.

[18] S. Czaplicki, D. Ogrodowska, R. Zadernowski, and D. Derewiaka, "Characteristics of biologically-active substances of amaranth oil obtained by various techniques," Polish Journal of Food and Nutrition Sciences, vol. 62, no. 4, pp. 235-239, 2012.

[19] J. Krulj, T. Brlek, L. Pezo et al., "Extraction methods of Amaranthus sp. grain oil isolation," Journal of the Science of Food and Agriculture, vol. 96, pp. 3552-3558, 2016.

[20] J.-Z. Yin, A.-Q. Wang, W. Wei, Y. Liu, and W.-H. Shi, "Analysis of the operation conditions for supercritical fluid extraction of seed oil," Separation and Purification Technology, vol. 43, no. 2, pp. 163-167, 2005.

[21] R. S. Mohamed and G. A. Mansoori, "The use of supercritical fluid extraction technology in food processing-featured article," Food Technology Magazine, vol. 20, pp. 134-139, 2004.

[22] G. Wejnerowska, P. Heinrich, and J. Gaca, "Separation of squalene and oil from Amaranthus seeds by supercritical carbon dioxide," Separation and Purification Technology, vol. 110, pp. 39-43, 2013.

[23] E. Naziri, S. B. Glisic, F. T. Mantzouridou, M. Z. Tsimidou, V. Nedovic, and B. Bugarski, "Advantages of supercritical fluid extraction for recovery of squalene from wine lees," The Journal of Supercritical Fluids, vol. 107, pp. 560-565, 2016.

[24] J.-Z. Yin, Q.-Q. Xu, W. Wei, and A.-Q. Wang, "Experiments and numerical simulations of supercritical fluid extraction for Hippophae rhamnoides L seed oil based on artificial neural networks," Industrial \& Engineering Chemistry Research, vol. 44, no. 19, pp. 7420-7427, 2005.

[25] P. Kraujalis and P. R. Venskutonis, "Supercritical carbon dioxide extraction of squalene and tocopherols from amaranth and assessment of extracts antioxidant activity," The Journal of Supercritical Fluids, vol. 80, pp. 78-85, 2013.

[26] D. Westerman, R. C. D. Santos, J. A. Bosley, J. S. Rogers, and B. Al-Duri, "Extraction of Amaranth seed oil by supercritical carbon dioxide," The Journal of Supercritical Fluids, vol. 37, no. 1, pp. 38-52, 2006

[27] AOAC, Official Methods of Analysis of the AOAC, eighteenth ed. AOAC Inc., USA, 2005

[28] T. Murakami, A. Yutani, T. Yamano, H. Iyota, and Y. Konishi, "Effects of Popping on Nutrient Contents of Amaranth Seed," Plant Foods for Human Nutrition, vol. 69, no. 1, pp. 25-29, 2014.

[29] P. Mercer and R. E. Armenta, "Developments in oil extraction from microalgae," European Journal of Lipid Science and Technology, vol. 113, no. 5, pp. 539-547, 2011.

[30] S. Schneider, Quality Analysis of Extra Virgin Olive Oils-Part 5 Nutritive Benefits-Determination of Squalene in Virgin Olive Oil, Agilent Technologies. Inc, 2013.

[31] A. Rojas-Ávila, A. Pimentel-Rodas, T. Rosales-García, G. Dávila-Ortiz, and L. A. Galicia-Luna, "Solubility of Binary and Ternary Systems Containing Vanillin and Vanillic Acid in Supercritical Carbon Dioxide," Journal of Chemical \& Engineering Data, vol. 61, no. 9, pp. 3225-3232, 2016.

[32] E. N. Aquino-Bolaños, L. Mapel-Velazco, S. T. Martín-del-Campo, J. L. Chávez-Servia, A. J. Martínez, and I. Verdalet-Guzmán, "Fatty acids profile of oil from nine varieties of Macadamia nut," International Journal of Food Properties, vol. 20, no. 6, pp. 1262$1269,2017$.

[33] X. He, J. Liu, L.-L. Cheng, and B.-J. Wang, "Quality properties of crispy winter jujube dried by explosion puffing drying," International Journal of Food Engineering, vol. 9, no. 1, pp. 99106, 2013.

[34] T. H. Gamel, J. P. Linssen, G. M. Alink, A. S. Mosallem, and L. A. Shekib, "Nutritional study of raw and popped seed proteins of Amaranthus caudatus L and Amaranthus cruentus L," Journal of the Science of Food and Agriculture, vol. 84, no. 10, pp. 1153-1158, 2004

[35] A. C. Nascimento, C. Mota, I. Coelho et al., "Characterisation of nutrient profile of quinoa (Chenopodium quinoa), amaranth (Amaranthus caudatus), and purple corn (Zea mays L.) consumed in the North of Argentina: Proximates, minerals and trace elements," Food Chemistry, vol. 148, pp. 420-426, 2014.

[36] P. Zapotoczny, M. Markowski, K. Majewska, A. Ratajski, and H. Konopko, "Effect of temperature on the physical, functional, and mechanical characteristics of hot-air-puffed amaranth seeds," Journal of Food Engineering, vol. 76, no. 4, pp. 469-476, 2006.

[37] G. Brunner, "Supercritical fluids: Technology and application to food processing," Journal of Food Engineering, vol. 67, no. 1-2, pp. 21-33, 2005.

[38] R. Abalone, A. Cassinera, A. Gastón, and M. A. Lara, "Some physical properties of amaranth seeds," Biosystems Engineering, vol. 89, no. 1, pp. 109-117, 2004.

[39] Y. Konishi, H. Iyota, K. Yoshida et al., "Effect of moisture content on the expansion volume of popped amaranth seeds by hot air and superheated steam using a fluidized bed system," Bioscience, Biotechnology, and Biochemistry, vol. 68, no. 10, pp. 2186-2189, 2004.

[40] C. H. Oritz-Estrada, C. Y. Díaz-Díaz, J. Cruz-Olivares, and C. Pérez-Alonso, "Coenzyme Q10 microparticles formation with supercritical carbon dioxide," Revista Mexicana de Ingeniería Química, vol. 14, pp. 49-59, 2015.

[41] E. K. Asep, S. Jinap, T. J. Tan, A. R. Russly, S. Harcharan, and S. A. H. Nazimah, "The effects of particle size, fermentation and roasting of cocoa nibs on supercritical fluid extraction of cocoa butter," Journal of Food Engineering, vol. 85, no. 3, pp. 450-458, 2008 . 
[42] N. Lebovka, E. Vorobiev, and F. Chemat, Enhancing Extraction Processes in the Food Industry, CRC Press, Boca Raton, FL, USA, 2011.

[43] K. S. Duba and L. Fiori, "Solubility of grape seed oil in supercritical $\mathrm{CO}_{2}$ : experiments and modeling," The Journal of Chemical Thermodynamics, vol. 100, pp. 44-52, 2016.

[44] E. Psomiadou and M. Tsimidou, "On the role of squalene in olive oil stability," Journal of Agricultural and Food Chemistry, vol. 47, no. 10, pp. 4025-4032, 1999.

[45] J. Kim, D. N. Kim, S. H. Lee, S. Yoo, and S. Lee, "Correlation of fatty acid composition of vegetable oils with rheological behaviour and oil uptake," Food Chemistry, vol. 118, no. 2, pp. 398-402, 2010.

[46] E. Tvrzicka, L.-S. Kremmyda, B. Stankova, and A. Zak, "Fatty acids as biocompounds: their role in human metabolism, health and disease-a review. Part 1: classification, dietary sources and biological functions," Biomedical Papers, vol. 155, no. 2, pp. 117130, 2011.

[47] A. Alegría and J. Cuellar, "Esterification of oleic acid for biodiesel production catalyzed by 4-dodecylbenzenesulfonic acid," Applied Catalysis B: Environmental, vol. 179, pp. 530-541, 2015.

[48] U. N. Das, "Beneficial effect(s) of n-3 fatty acids in cardiovascular diseases: but, why and how?" Prostaglandins, Leukotrienes and Essential Fatty Acids, vol. 63, no. 6, pp. 351-362, 2000.

[49] E. Scorletti and C. D. Byrne, "Omega-3 fatty acids, hepatic lipid metabolism, and nonalcoholic fatty liver disease," Annual Review of Nutrition, vol. 33, pp. 231-248, 2013.

[50] C. Torrejón and R. Uauy, "Calidad de grasa, arterioesclerosis y enfermedad coronaria: efectos de los ácidos grasos saturados y ácidos grasos trans," Revista Médica de Chile, vol. 139, no. 7, pp. 924-931, 2011.

[51] M. Canakci and J. H. Van Gerpen, "Biodiesel production from oils and fats with high free fatty acids," Transactions of the ASAE, vol. 44, no. 6, pp. 1429-1436, 2001.

[52] S. C. Cermak, R. L. Evangelista, and J. A. Kenar, "Distillation of natural fatty acids and their chemical derivatives," in In Distillation-Advances from Modeling to Applications, pp. 109140, InTech, 2012.

[53] Y. Basiron, "Palm oil production through sustainable plantations," European Journal of Lipid Science and Technology, vol. 109, no. 4, pp. 289-295, 2007.

[54] R. Bruni, A. Guerrini, S. Scalia, C. Romagnoli, and G. Sacchetti, "Rapid techniques for the extraction of vitamin $\mathrm{E}$ isomers from Amaranthus caudatus seeds: ultrasonic and supercritical fluid extraction," Phytochemical Analysis, vol. 13, no. 5, pp. 257-261, 2002.

[55] F. Aranda, S. Gómez-Alonso, R. M. Rivera Del Álamo, M. D. Salvador, and G. Fregapane, "Triglyceride, total and 2-position fatty acid composition of Cornicabra virgin olive oil: comparison with other Spanish cultivars," Food Chemistry, vol. 86, no. 4, pp. 485-492, 2004.

[56] A. Mancini, E. Imperlini, E. Nigro et al., "Biological and nutritional properties of palm oil and palmitic acid: Effects on health," Molecules, vol. 20, no. 9, pp. 17339-17361, 2015.

[57] T. Hauß, S. Dante, N. A. Dencher, and T. H. Haines, "Squalane is in the midplane of the lipid bilayer: Implications for its function as a proton permeability barrier," Biochimica et Biophysica Acta (BBA) - Bioenergetics, vol. 1556, no. 2-3, pp. 149-154, 2002.

[58] C. Ofori-Boateng and K. T. Lee, "Sustainable utilization of oil palm wastes for bioactive phytochemicals for the benefit of the oil palm and nutraceutical industries," Phytochemistry Reviews, vol. 12, no. 1, pp. 173-190, 2013.
[59] N. Al-Darmaki, T. Lu, B. Al-Duri et al., "Isothermal and temperature gradient supercritical fluid extraction and fractionation of squalene from palm fatty acid distillate using compressed carbon dioxide," The Journal of Supercritical Fluids, vol. 61, pp. 108-114, 2012.

[60] E. A. Tosi, E. D. Ré, R. Masciarelli, H. Sánchez, C. Osella, and M. A. De La Torre, "Whole and defatted hyperproteic amaranth flours tested as wheat flour supplementation in mold breads," LWT-Food Science and Technology, vol. 35, no. 5, pp. 472-475, 2002. 

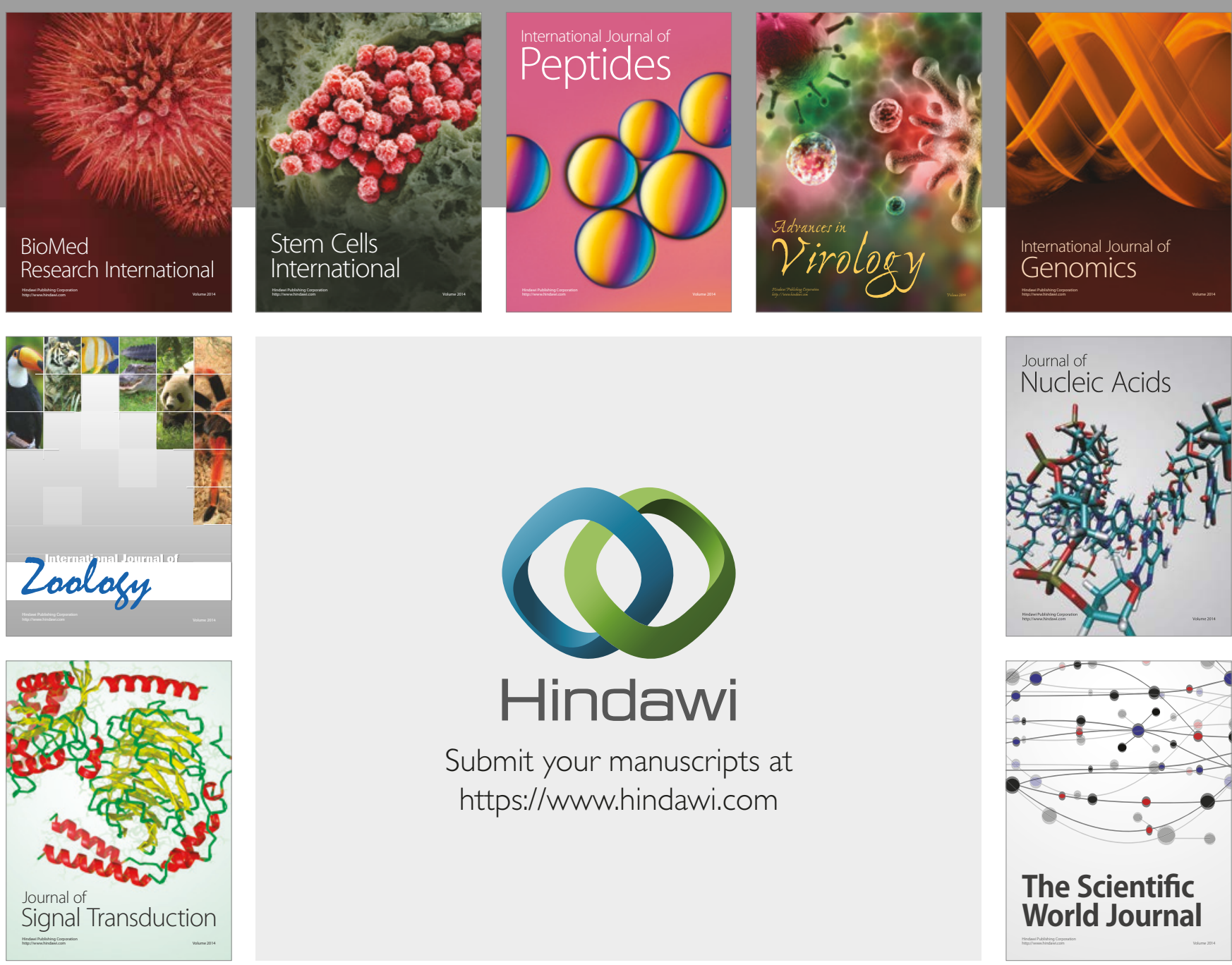

Submit your manuscripts at

https://www.hindawi.com
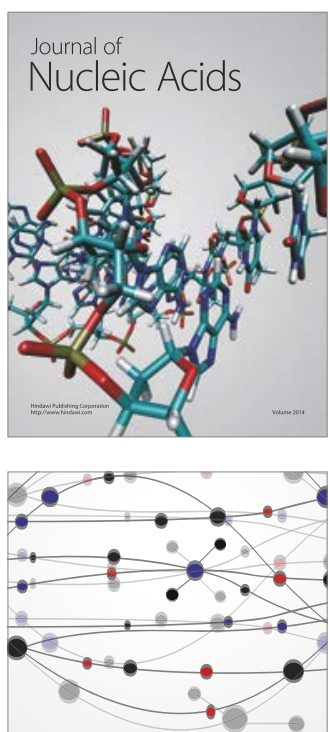

The Scientific World Journal

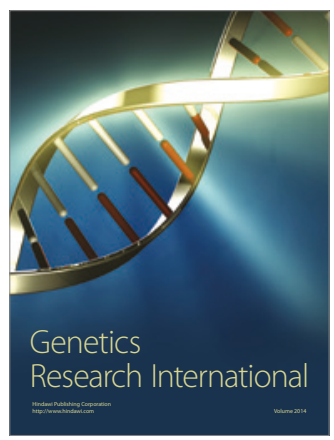

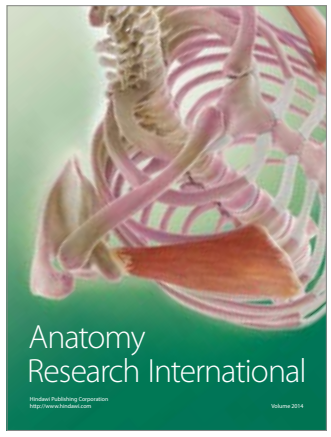

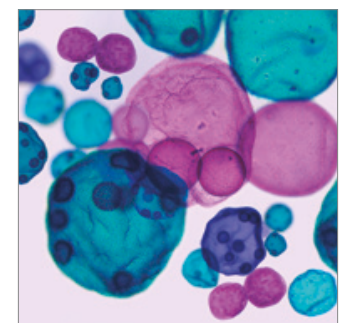

International Journal of Microbiology
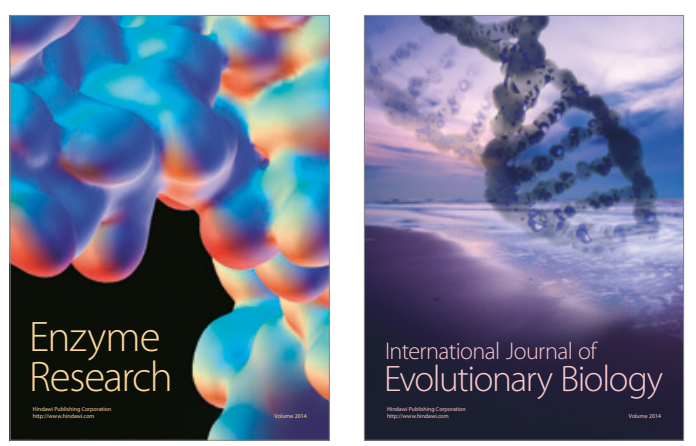
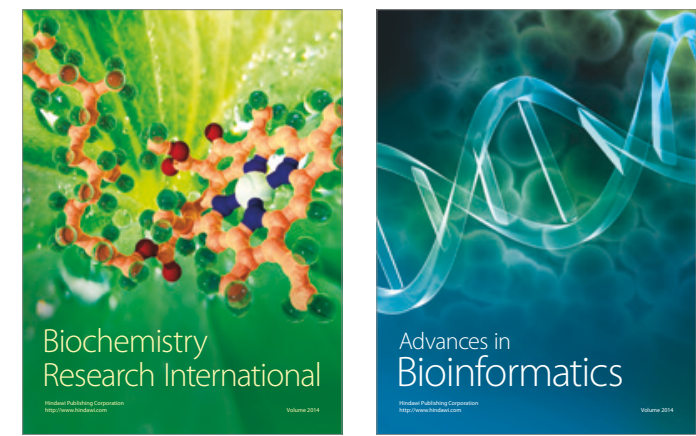

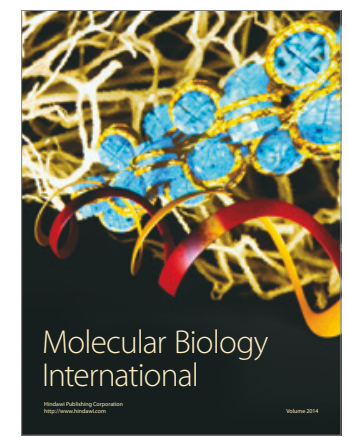

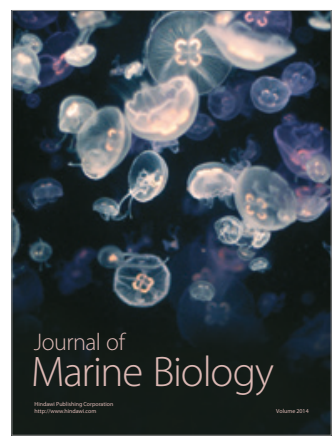

